\title{
The Effect of Product Innovation on Consumer Interest in the Purchase of Bottled Tea Products at PT. Sinar Sosro Medan
}

\author{
Sarman Sinaga ${ }^{1}$, Jonner Lumban Gaol $^{2}$, Reza Nurul Ichsan ${ }^{3}$ \\ ${ }^{1,2}$ Universitas Darma Agung Medan, Indonesia \\ ${ }^{3}$ Universitas Pembinaan Masyarakat Indonesia \\ sarmansinaga17@gmail.com, jonnerlumbangaol99@gmail.com,rezaichsan31@gmail.com
}

\begin{abstract}
Product innovation is a guideline that is expected to influence consumer interest in purchases. The problem formulation in this study is whether there is a significant influence of product innovation on consumer interest in purchasing. And the purpose of this research is to find out if there is a significant relationship between product innovation and consumer interest in purchasing Bottled Tea Products at PT Sinar Sosro Medan. The research approach carried out is a quantitative type of primary data source. This study used a simple linear regression analysis model using SPSS (Statistica Product and Service Solution) software version 21.0. The number of samples in this study was as many as 78 customers. The results of this study showed a regression equation where $Y=1,807+0.5 X+e$, which means product innovation has a positive influence on consumer interest. This indicates that if there is an increase in product innovation by 1 unit, it will be followed by an increase in consumer interest by 0.5 units. Based on the significance test shows a significant influence of product innovation on consumer interest, it is seen that the significance value for the influence of $X$ on $Y$ is $0.00<0.05$ and thitung value of $5.626>$ ttabel 2.6403 means that if product innovation is improved then consumer interest will also increase. And from the test results of the coefficient of determination in nila $R$ Square of 0.294 this shows that $29.4 \%$ of consumer interest is influenced by product innovation and the remaining $71.5 \%$ is influenced by other variables outside of this study. This will be even better if product innovation continues to be implemented and improved with the increasing interest of consumers, because of PT employees. Sinar Sosro will have the opportunity to channel its creativity with better innovation ideas.
\end{abstract}

Keywords

product innovation;

consumer interest

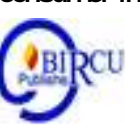

\section{Introduction}

Innovation is a competency that must be developed by every company in Indonesia. Creativity and innovation that develops can be seen through the presence of creative and innovative human beings, so that companies can create brilliant ideas about the best products and services. Creative people have a high innovation in changing things in a better direction and benefiting the company.

This research was conducted at PT Sinar Sosro Medan, a beverage producing company that has been quite popular in the ears of the public. But over time, competition in the business sector is getting tighter with the birth of many similar companies with a number of attractions. To be able to survive and even be at the forefront of course the company must make sustainable innovations. A product without innovation will only be a monotonous product and will slowly be left behind by its customers. The innovation in 
question can certainly be implemented in many ways such as creating new flavor variations and the creation of more attractive packaging.

Continuous innovation in a company is a fundamental need that in turn will be able to create a competitive advantage. Thus innovation is an important function of management because innovation will determine a superior business performance. Innovation will increasingly be important as a tool for survival, not only growth but also in increasingly intense competition.

\section{Review of Literatures}

\subsection{Product Innovation}

According to Atalay, et al. (2013) stated that product innovation is the introduction and development of new types of goods or services that are different from before and complement the shortcomings of the previous findings with more emphasis on quality. Companies in making product innovations must pay attention to market orientation because knowledge of market orientation is the key to successful product innovation that will be produced (Wiwoho, 2012). According to (Pardi et al., 2014; Tung, 2012; Killa, 2014; Utaminingsih, 2016) states that innovation has a significant positive effect on marketing performance. Windahl (2015) itself divides product innovation into 4 types, including modular innovation, architectural innovation, incremental innovation and radical innovation, this terminology applies to the customers and suppliers. While radical innovations show a fundamental change in new services and provide real service benefits (Cheng \&Krumwiede, 2012). Product innovation alone cannot produce competitive advantage and sufficient or sustainable company growth (Shelton, 2009: 38).

\subsection{Consumer Interest}

A consumer behavior is interesting, unique and dynamic attributesof the consumers. Kotler (2005: 201) describes it as individuals, groups, and organizations choose, buy, use and utilize goods, services, ideas or experiences in order to satisfy their needs and desires. It is an action getting, consuming, and consuming the products and services including the decision process, Husain Umar (2003: 50).It can be generalized that consumer behavior is a decision taken from an action, done through the process stages of previous thinking by individuals or groups or an organizational institution using the products or services.Service, in this case, is either a tangible or intangible provided by service providers. It can be individual or organizational organizations to meet the main needs or as the needs of supporting users. The marketers need to understand how customers evaluate their services (Cuningham, 2000). Thus, the issue of managing and measuringservice quality is a focus in this research (Sukesi and Yunus, 2018).

\section{Research Methods}

The research was conducted at PT. SinarSosro Medan, which is located on the highwayTg. Morawa Km. 14.5 Deli serdang Medan North Sumatra. The population used in this study was a regular customer of PT. Sinar Sosro Medan made a purchase from January 2018 to January 2019 with 352 customers. Slovin formula calculation results obtained the number of customers who were used as a research sample of 78 customers. The sampling technique used is Purposive random Sampling i.e. "the sample is selected with certain considerations. The consideration of the sample taken is customers who shop at PT. Sinar Sosro Medan. 
The data source in this research is data obtained from PT. Sinar Sosro which is located in Tanjung Morawa, Kab. Deli Serdang.The sample used is the consumer of PT Sinar Sosro as many as 78 people, this number is taken based on calculations using the formula Slovin. Data retrieved including Primary data and secondary data: 1). Primary data is the collection of data sourced from the results of research in the field or often also called field research. Primary data collection is conducted through various means such as through questionnaires, interviews, surveys, observations, experiments and others. 2) Secondary data is the collection of information sourced from textbooks, journals, documents and other information related to this research that contains the views of management experts.

The test tool used to analyze the hypothesis in this study is Simple Linear Regression Analysis to test product innovation-free variables against variables tied to consumer interest in making purchases.

\section{Results and Discussion}

\subsection{Research Results \\ a. Validity Test}

Table 1. Validity of Product Innovation Variables

\begin{tabular}{|c|c|c|c|}
\hline Statements & Corrected Item-Total Correlation & rtable $_{1}$ & Information \\
\hline 1 & 0,665 & 0,220 & Valid \\
\hline 2 & 0,483 & 0,220 & Valid \\
\hline 3 & 0,470 & 0,220 & Valid \\
\hline
\end{tabular}

Source: Researcher Processed Data 2019

Table 2. Validity of Consumer Interest Variables

\begin{tabular}{|c|c|c|c|}
\hline Statements & Corrected Item-Total Correlation & rtable & Information \\
\hline 1 & 0,493 & 0,220 & Valid \\
\hline 2 & 0,227 & 0,220 & Valid \\
\hline 3 & 0,418 & 0,220 & Valid \\
\hline 4 & 0,423 & 0,220 & Valid \\
\hline
\end{tabular}

Source: Researcher Processed Data 2019

After the test, it can be known that all statement items have an item-total correlation or coefficient of more than the value of $r$ table that is 0.220 then the statement item is declared valid.

\section{b. Reliability Test}

Table 3. Product Innovation Variable Reliability Test Results

Reliability Statistics

\begin{tabular}{|r|r|}
\hline Cronbach's Alpha & N of Items \\
\hline, 712 & \\
\hline
\end{tabular}

Source: SPSS Processing Results

Table 4. UJi Reliability variable Consumer Interest

Reliability Statistics

\begin{tabular}{|r|r|}
\hline Cronbach's Alpha & N of Items \\
\hline, 602 & \\
\hline
\end{tabular}

Source: SPSS 2019 processing results 
While the reliability test obtained from cronbach alpha value of $0.712>0.6$ and 0.602>.0.6 then the measuring instrument can be said to be reliable and fall into the category of very high reliability.

c. $\mathbf{t}$ Test

Table 5. Test Result $\mathrm{t}$

Coefficients $^{\mathrm{a}}$

\begin{tabular}{|c|c|c|c|c|}
\hline \multirow[t]{2}{*}{ Model } & \multicolumn{2}{|c|}{$\begin{array}{c}\text { Unstandardized } \\
\text { Coefficients }\end{array}$} & \multirow[t]{2}{*}{$\mathrm{t}$} & \multirow[t]{2}{*}{ Sig. } \\
\hline & B & Std. Error & & \\
\hline $\begin{array}{ll} & \text { (Constant) } \\
\text { X_inovasi }\end{array}$ & $\begin{array}{r}1,807 \\
, 500\end{array}$ & $\begin{array}{l}, 346 \\
, 089\end{array}$ & $\begin{array}{l}5,218 \\
5,626\end{array}$ & $\begin{array}{l}, 000 \\
, 000\end{array}$ \\
\hline
\end{tabular}

Source: SPSS Processing Results

1. Dependent Variable: Y buying interest

The basis of t-test decision making is if:

$\mathrm{t}$-calculate $>\mathrm{t}$-table and value significance $<0.05$ then free variables have a significant effect on bound variables; $b$. $t-$ count $<\mathrm{t}$-table and value significance $>0.05$ then free variables have no significant effect on bound variables.

Conclusion of t-test results:

From the table above, it can be seen that thitung value is 5.626 greater than the tttabel of 2.6403 with a value of sig $0.000<0.05$. So it can be concluded that product innovation variables have a significant influence on consumer interest variables.

\section{d. Coefficient of Determination}

Coefficients of determination are used to find out how much influence free variables have on bound variables. The value of the determinant coefficient is determined by the value of $\mathrm{R}$ square.

Table 6. Coefficient of Determination Model Summary ${ }^{b}$

\begin{tabular}{|l|r|r|r|}
\hline Model & \multicolumn{1}{|c|}{$\mathrm{R}$} & \multicolumn{1}{|c|}{ R Square } & Adjusted R Square \\
\hline 1 &, $542^{\mathrm{a}}$ &, 294 &, 285 \\
\hline
\end{tabular}

a. Predictors: (Constant), X_inovasi

b. Dependent Variable: Y buying interest

Source: SPSS output data

From the table above it can be seen that the value of R Square is 0.294 . So it can be concluded that product innovation only affects consumer interest in the $29.4 \%$ increase while there are still other variables that can be used to test the influence on consumer interest in purchases of $70.6 \%$

\section{e. Simple Linear Regression}

Regression is a measuring instrument also used to measure the exist or not of collegiation between variables. Regression test results from this study can be seen in the table below 
Table 7. Simple Linear Regression Test

Coefficients ${ }^{\mathrm{a}}$

\begin{tabular}{|ll|r|r|r|}
\hline \multirow{2}{*}{ Model } & \multicolumn{2}{|c|}{ Unstandardized Coefficients } & \multicolumn{1}{c|}{$\begin{array}{c}\text { Standardized } \\
\text { Coefficients }\end{array}$} \\
\cline { 2 - 5 } & \multicolumn{1}{|c|}{ B } & Std. Error & \multicolumn{1}{c|}{ Beta } \\
\hline \multirow{2}{*}{1} & (Constant) & 1,807 &, 346 & \\
\cline { 2 - 5 } & X_inovasi &, 500 &, 089 &, 542 \\
\hline
\end{tabular}

a. Dependent Variable: Y buying interest

Source: SPSS Processed Data 2019

Based on the table above, the research regression formula is found as follows:

$$
\mathrm{Y}=\mathbf{1 , 8 0 7}+\mathbf{0 . 5 X}
$$

Description of the above regression model as follows: 1). Constants of 1,807 indicate that if independent variables are eliminated then the consumer's buying interest is 1,807.2) $\mathrm{A} b$ value of 0.5 indicates that any increase in product innovation by $1 \%$ will be followed by an increase in consumer interest of 0.5 assuming other variables are considered to have no effect.

\subsection{Discussion}

Based on the table obtained thitung of 5,626. The distribution table t searched $\alpha=5 \%$ obtained for the tyable of 2.6403. The value of thitung >ttabel then Ho is rejected, meaning that product innovation has a significant influence on consumer interest in purchasing bottled tea products at PT. Sinar Sosro Medan. From the test results can also be seen that the value of adjusted R Square is 0.285 . So it can be concluded that product innovation only affects consumer buying interest by $28.5 \%$ while there are still other variables that can be used to test the influence on consumer interest by $71.5 \%$.

The results of this test are in line with the writing carried out by Nauli Sidabalok (2013) who wrote on the effect of product innovation on consumers' buying interest in PT products. Indofood Medan. Test t writing results showed a value of 3,567 > 2,262, so it can be concluded that product innovation affects consumers' buying interest. Ferdinan's writing on the effect of product innovation on buying interest in Nokia mobile products also draws the same conclusion that he concluded that Product Innovation has a positive effect on consumers' buying interests. This illustrates that consumer interest will increase when the company releases the latest product innovations, and this attracts the attention of comment.

\section{Conclusion}

Based on the results of data analysis and evaluation of the Effect of Product Innovation on Consumer Interest in Purchasing Bottled Tea Products at PT Sinar Sosro Medan, the authors draw the following conclusions: 1). The significance test shows that product innovation has a very significant influence on consumer interest in making purchases. So that every innovation made by the company will attract consumers to make purchases. 2). Regression tests showed that innovation directly influenced consumers' buying interest. Which means that every $1 \%$ of product innovations carried out give an effect of an increase of 0.5 for consumers' buying interests. 3). R Square value of 0.294 indicates that there are still many other variables that affect consumer buying interest. Product innovation only affects $29.4 \%$ of the total data factor that affects consumers' buying interest. 


\section{References}

Arikunto, Suharsimi. 2012. Prosedur Penulisan Suatu Pendekatan Praktik. Jakarta: Rineka Cipta

Atalay, M., Anafarta, N., \&Sarvan, F. (2013). The relationship between innovation and firm performance: An empirical evidence from Turkish automotive supplier industry. Procedia-Social and Behavioral Sciences 75 (2). 226-235

Cheng, C. C., \&Krumwiede. D. (2012). The role of service innovation in the market orientation new service performance linkage. Technovation. 32 (7-8). 487-497

Cunningham, Laurence. 2000. Methodological Triangulation in Measuring Public

Transportation Srvice Quality, in Transportation Journal, Fall. 2000.

Ghozali, Imam. 2012. Aplikasi Analisis Multivariate dengan Program SPSS. Semarang: BPFE Undip

Ichsan, R., \& Nasution, L. (2021). Sosialisasi Pelatihan Disiplin Kerja Karyawan Restaurant Kenanga Garden Medan. PKM Maju UDA, 1(3), 127-132. doi:10.46930/pkmmajuuda.v1i3.885

Ichsan, R. N., Suparmin, S., Yusuf, M., Ismal, R., \& Sitompul, S. (2021). Determinant of Sharia Bank's Financial Performance during the Covid-19 Pandemic. Budapest International Research and Critics Institute (BIRCI-Journal): Humanities and Social Sciences, 4(1), 298-309.

Ichsan, Reza Nurul; SE, M. M. Bahan Ajar Manajemen Sumber Daya Manusia (MSDM). CV. Sentosa Deli Mandiri

J. Supranto. 2013. Teknik Sampling Untuk Survey dan Eksperimen. Jakarta: Rineka Cipta

Kotler, Philip, dan Gary Amstrong 2012. Manajemen Pemasaran: terjemahan Hendra Teguh, Ronny, A, Rusli dan Benjamin Molan, edisi millenium, Penerbit PT. Indeks, Jakarta

Kotler, P., (2005). Manajamen Pemasaran. Jilid 1 dan 2. Jakarta: PT. Indeks Kelompok Gramedia.

Mas'ud, Fuad. 2014. Survai Diagnosis Organisasional Konsep \& Aplikasi. Semarang: Badan Penerbit Universitas Diponegoro.

Mohammad Yusuf, \& Reza Nurul Ichsan. (2021). Analysis of Banking Performance in the Aftermath of The Merger of Bank Syariah Indonesia in Covid 19. International Journal of Science, Technology \& Management, 2(2), 472-478. https://doi.org/10.46729/ijstm.v2i2.182

Nasution, L., \& Ichsan, R. (2021). Sosialisasi Peluang Usaha Bank Sampah Dalam Peningkatan Pendapatan Masyarakat Di Masa Covid 19. PKM Maju UDA, 1(3), 107-112. doi:10.46930/pkmmajuuda.v1i3.882

Nasution, L., \& Nurul Ichsan, R. (2021). Pengaruh Penerapan Kepemimpinan Terhadap Kinerja Pegawai Pada Kantor Dinas Pendidikan Kabupaten Karo. Jurnal Ilmiah METADATA, 3(1), 308-320. Retrieved from http://ejournal.steitholabulilmi.ac.id/index.php/metadata/article/view/59

Nurul Ichsan, R., \& Lumban Gaol, J. (2021). Pengaruh Kepemimpinan Terhadap Disiplin Kerja Pegawai Pada Kantor Dinas Pendidikan Kabupaten Karo. Jurnal Ilmiah METADATA, 3(1), 344-355. Retrieved from http://ejournal.steitholabulilmi.ac.id/index.php/metadata/article/view/62

Pardi, Suharyono, Imam, S., Zainul, A. (2014). The Effect of market orientation and entrepreneurial orientation toward learning orientation, innovation, competitive advantages and marketing performance.European Journal of Business and Management. 6 (21). 69-80. 
Paul N, Bloom dan Louise N, Boone. 2011. Strategi Pemasaran Produk: 18 Langkah Membangun jaring Pemasaran Produk Yang Kokoh. Jakarta: Prestasi Pustakarya.

Reid, Mike C. and Brady, Erica. 2014. "Relationship between Market Orientation, Management and Execution of NPD and NPD Program Performance". Journal of Marketing P: 969-975.

Shelton, R. (2009). Integrating product and service innovation. Research-Technology Management. 52 (3). 38-44.

Sugiyono. 2014. Metode Penulisan Bisnis. Bandung: CV Alfabeta.

Sukesi and Yunus, E. (2018). Service Quality in Public Transport Services of the Provicial Intercity Transportation (AKDP) in East Java Indonesia. Budapest International Research and Critics Institute-Journal (BIRCI-Journal). P. 161-169.

Swastha Basu dan T. Hani Handoko. 2010. Manajemen Pemasaran Analisa Perilaku Konsumen. Jakarta: Salemba Empat.

Tjiptono, Fandy. 2012. Pemasaran Strategik. Yogyakarta: Andi Offset

Triton PB. 2013. Marketing Strategi Meningkatkan Pangsa Pasar dan Daya Saing. Yogyakarta: Tugu Publisher

Usmara, Usi. 2012. Pemikiran Kreatif Pemasaran. Yogyakarta: Amara Books

Wahyono. 2012. "Orientasi Pasar dan Inovasi: Pengaruhnya Terhadap Kinerja Pemasaran (Studi Kasus Pada Industri Meubel di Kabupaten Jepara)".

Wiwoho, G. (2012). Analisis pengaruh orientasi pasar, orientasi pembelajaran terhadap inovasi produk dan kinerja pemasaran (Studi pada sentra industry kecil rumah tangga kerajinan anyaman pandan di Desa Grenggeng kecamatan Karanganyar kabupaten Kebumen). Jurnal Manajemen 12 (2). 34-50

Yusuf, M., Ichsan, R., \& Saparuddin, S. (2021). Determinasi Investasi Dan Pasar Modal Syariah Terhadap Pertumbuhan Ekonomi Di Indonesia. JEpa, 6(1), 397-401. Retrieved from http://jurnal.pancabudi.ac.id/index.php/jepa/article/view/1121 